\title{
Good Practices in Updating Land Information Systems that Used Unconventional Approaches in Systematic Land Registration
}

\author{
Mireille Biraro $^{1, *}$, Jaap Zevenbergen ${ }^{2}(\mathbb{D})$ and Berhanu Kefale Alemie ${ }^{1(D)}$ \\ 1 Institute of Land Administration, Bahir Dar University, Bahir Dar P.O. Box 79, Ethiopia; \\ berhanu.kefale@bdu.edu.et \\ 2 Faculty of Geoinformation Science and Earth Observation (ITC), University of Twente, \\ 7522 NB Enschede, The Netherlands; j.a.zevenbergen@utwente.nl \\ * Correspondence: biraro.mireille@ines.ac.rw
}

check for updates

Citation: Biraro, M.; Zevenbergen, J.; Alemie, B.K. Good Practices in Updating Land Information Systems that Used Unconventional Approaches in Systematic Land Registration. Land 2021, 10, 437. https://doi.org/10.3390/land10040437

Academic Editor: Robin McLaren

Received: 18 March 2021

Accepted: 15 April 2021

Published: 20 April 2021

Publisher's Note: MDPI stays neutral with regard to jurisdictional claims in published maps and institutional affiliations.

Copyright: (c) 2021 by the authors. Licensee MDPI, Basel, Switzerland. This article is an open access article distributed under the terms and conditions of the Creative Commons Attribution (CC BY) license (https:// creativecommons.org/licenses/by/ $4.0 /)$.

\begin{abstract}
To properly govern people-to-land relationships, there is a need to formally recognize land rights, and for this to bring recognizable societal change, the established Land Information System (LIS) has to be updated continuously. Though existing literature suggests different parameters to consider when updating an LIS, little is said on how countries are doing this, especially when unconventional approaches through systematic land registration were initially used. This paper comes up with recommendable good practices where the suggested needs for updating land records were made workable. Nine countries with similar data collection procedures for the initial registration were selected based on literature study; questionnaires designed and distributed to LIS experts from each country using internet; and the collected data were analyzed qualitatively. Fortunately, all the case countries possess infrastructure supporting land records updating (procedures, mobilization means, institutional and legal frameworks, and so on). For the majority, the systems are simplified; registration fees are reasonable; services are decentralized; the database is accessible by citizens and local officers; staff are trained; the system effectiveness is assessed; and the political support is offered. However, the procedures are long, data sharing is inexistent, financial and technical sustainability is uncertain, and many different institutions are involved in the registration. Whilst updating used to appear as a forgotten activity, good practices now exist.
\end{abstract}

Keywords: good practices; updating land records; systematic land registration; unconventional approach

\section{Introduction}

Land registration emerged throughout the history of humanity for publicity of land records. This helps landholders and land administrators to know what belongs to whom and for the State to know all land units liable for taxation or other services [1]. Countries are using different methods when establishing their Land Information System (LIS) as there is no 'one-fit-for-all type' approach. LIS refers to a system made of land records; human and technical resources; and appropriate procedures and techniques to collect, analyze, maintain, disseminate, and use this information [1,2]. These records on land can be collected through sporadic or systematic land registration depending on the purpose, on available technologies, and/or on who is funding the activity (donors, government, or landholders) [3]. The systematic land registration is often compulsory, done plot by plot to cover the entire area under registration, regardless of the wishes of landholders $[2,4]$. Sporadic land registration, on the other hand, can either be voluntary (at the initiative of the landholder) or compulsory (during land transfer) [2]. Systematic registration is strongly recommended in the case of first registration [1] as it allows to have a complete database for the area under registration, low cost per unit of registration (as the registration covers many units simultaneously [1]), less recorded disputes (since there is a possibility to appeal and the registration is done in the presence of local community [3]), and a faster process (as 
photogrammetric techniques are often used to demarcate boundaries). However, the initial cost may be high due to the fact that resources are needed for photogrammetric mapping, to equip registration offices, train staff, hire external experts to design the procedures and proceedings, and so on [1,3]. That is why this approach is usually adopted through government- or donor-funded projects [3].

Systematic land registration is the one that is mostly recommended to developing countries $[1,4,5]$ due to insufficient financial and human resources and yet the property rights have to be registered. As this registration type covers a vast area and involves many people, unconventional approaches that are cheap and faster are suggested instead of using standardized methods that are longer and expensive. Contemporary philosophies in the area suggest the fit for purpose [6] and pro-poor land recordation [7] approaches when recording land as they are flexible, inclusive, participatory, affordable, and upgradable. These unconventional approaches have become popular in the developing world. Kenya, Nepal, and Thailand are the oldest cases [1,3,4,8]; while Ethiopia, Namibia, and Rwanda are the recent ones [6,9-12]. Though there are some particularities in each program, in all these cases, a considerable number of parcels was systematically registered through the use of unconventional approaches.

Nowadays, keeping the collected land records up to date seems to be more challenging than establishing an LIS. Though existing literature suggests different parameters to consider when updating an LIS, little is said on how countries are doing this, especially when unconventional approaches through systematic land registration were initially used. This paper provides good practices used to update an LIS that is originally developed through unconventional approaches and systematic land registration.

The paper contains six sections. The first one gives a background followed by the methodology used for data collection. Theoretical perspectives on updating come as the third section whereas a description of the land registration programs in the case study countries follows. The fifth section presents the analysis and the discussion done on the findings and the conclusion comes as the last and sixth section.

\section{Materials and Methods}

The selection of countries that have systematically registered their land by using unconventional approach was done through an extensive systematic literature review. The snowballing approach, often used in systematic literature review [13,14], helped to find publications on various land registration programs. The first entry point was to find a set of publications done on land registration programs and to perform a backward iteration (looking in the list of the initial reference) and a forward iteration (identifying references citing the initial references) [13]. 'Fit for purpose land administration: guiding principles for countries implementation' [5] and 'Securing Africa's Land for Shared Prosperity: a program to scale up reforms and investments' [11] are two publications that helped in this exercise. Seventeen (17) countries were found in the first round, some referred to as those that successfully implemented a national land registration using an unconventional approach [5] while others conducted land governance reforms by using faster and cost effective approaches [11]. To find more about the registration programs in each of these countries, backward and forward iterations were performed by using the references provided in the two publications.

The second entry point was the cadastral template website (www.cadastretemplate.org (accessed on 6 May 2020)) as it provides extensive information on the historical development of cadastral systems in different countries. By the time of accessing this website, fifty-seven (57) countries around the world had uploaded information concerning the development of their cadastral system. As this paper focuses on countries that systematically registered land, a selection was done and only fifteen (15) were kept (as they indicated that they used this approach).

From the two rounds, thirty-two (32) countries were identified. As Ethiopia appeared twice, the total number became thirty-one (31) countries. For all these countries, more 
publications were searched in order to find out when the initial land registration was done, for what purpose, and how land records were collected. The main sources of documentation were World Bank and FIG publications as experiences from these registration programs are often shared in their annual conferences. Additionally, a general search on World Wide Web through google scholar was done in order to access international journals that published work on the registration programs from the selected countries. Throughout the reading, two more countries that systematically registered their land were added making a total of thirty-three (33) countries (see the Appendix A for the list).

Guided by the question of how the land records were initially collected, a further refinement was done. Among the thirty-three (33) countries, eleven (11) were kept. These are countries that did a systematic land registration (a considerable number of parcels were registered), the registration program was not a pilot project, and unconventional approaches were used. Regarding the use of unconventional approaches, not all the criteria provided by Enemark [6] and Zevenbergen [7] could be assessed through literature. That is why a few criteria were applied in the assessment being participatory and flexible mapping (which does not require high professional training); affordability (no expensive process); and the co-management of the process (involvement of local citizens) [6,7]. Though Armenia and Vietnam fulfilled the selection criteria, they were dropped at the end as the contacted land experts were unable to participate in the research. The final nine (9) countries for which the land registration programs were explored in depth are listed in Table 1.

Table 1. Explored land registration programs.

\begin{tabular}{ccr}
\hline$\#$ & Country & Land Registration Program \\
\hline 1 & Ethiopia & 1st and 2nd level rural land registration (in 1998 and 2013 until now) \\
\hline 2 & Kenya & Registration of Native Reserves (1965-1966 until now) \\
\hline 3 & Rwanda & Land Tenure Regularization (2009 to 2013) \\
\hline 4 & Thailand & Land Titling Program (1984 to 2004) \\
\hline 5 & Kyrgyzstan & Registration of Land and Real Estates (2000 to 2007) \\
\hline 6 & Namibia & Communal Land Registration (2003 up to now) \\
\hline 7 & Nepal & Systematic registration (1965 to 1995) \\
\hline 8 & Mexico & Certification of Ejido (communal land) (1992 to 2006) \\
\hline 9 & Cambodia & Land Management and Administration Project (2002 to 2013)
\end{tabular}

For these countries, contact was made with LIS professionals working in the land sector and researchers who published on the registration programs in order to know mechanisms in place to update the collected land records. Most literature suggests sixteen (16) parameters to consider when updating an LIS sustainably. Accordingly, a questionnaire with both open-ended and closed questions was designed. Questions were asked about the identified registration programs, the existing process for updating the collected land records, and the technical structure of the database storing these records. The questionnaire was distributed to at least two (2) LIS experts for each country using internet (email, survey monkey or a virtual video discussion). The selection was purposively done, privileging those who could potentially provide the needed information. Snowballing also helped to reach more experts as those contacted linked to others. Out of the seventy-eight (78) people contacted via email, forty-five (45) replied among which twenty-eight (28) responded to the questionnaire. The collected data are analyzed qualitatively.

\section{Theoretical Perspectives on Updating Land Records}

Land records are very dynamic, as people-to-land relationships do change regularly, and need to be kept up to date. The term updating refers to the recording of any change from the real world into the system as soon as it occurs. It is a daily exercise that requires 
adequate level of trained professionals and communities willing to contribute to the updating process [15].

Capturing the real-time change of land rights into the database is critical as without it, the land system loses relevance and is replaced by an informal system [3]. Without regular updating, there is a high risk of going back to the previous situation, and even worse. Outdated land records may be used to cheat those who are less knowledgeable, thus creating a critical situation for the Land Administration System (LAS). The later refers to an infrastructure of implementing land policies and land management strategies in support of sustainable development [3]. LIS is a fundamental infrastructure for LAS [3] as it allows to secure land rights, undertake land/property valuation and taxation, plan and control the use of land, and implement utilities/infrastructures and construction planning [6].

When the database is up to date, records on land tenure allow a secured land market: Potential buyers may check whether they are dealing with 'all' legitimate right holders or if there is no encumbrance attached to the right (unpaid taxes, disputes, etc.) $[16,17]$. Thus, the buyer would be safe when paying or, later on, investing in the acquired land as there is no fear for probable eviction by other right holders who were not informed about the transaction.

With updated records on land value, banks may trust the system and rely on its information to issue loans by accepting land as collateral [18-20]. The loan can even be based on the recorded value, in the database, of the land/property being mortgaged. However, if the banks do not trust the system, using land to get a loan may be difficult, even impossible, albeit it is stipulated in the law [21].

The taxation process may be done smoothly when the records on location and value are up to date. It may be possible to identify taxable land/property and their holders. Thus, the government would rely on the revenues from land taxes/leases when planning the yearly national budget.

The updated records about how the land is used are crucial for planning purpose and for efficient land management $[3,18]$. It allows monitoring changes. The national land use plan may be developed based on the actual situation and avoids unnecessary expropriation and/or relocation of people. For all those places for which the use has to be changed, a proper implementation plan may be done based on updated evidence. Encroachment into sensitive areas (wetlands, forests, water bodies) or national utilities (airport, roads) may not occur as any change from the existing situation is controlled. Well-controlled land use may lead to land development. The development projects or private investments are carried out on suitable and/or vacant land. It may be known beforehand that the suitable land for a particular investment/project is (not) vacant, thus proper measures must be taken for a smooth implementation. Besides, in the case of negotiation, expropriation, or relocation, information on the legitimate right holders, their rights, what they use the land for, and the value of their properties is obtained from the system and the planning done accordingly. It may save money and time supposed to be spent on new surveys.

The information on who is the person (natural/non-natural) that has what type of right on which piece of land has to be known as it is. Unfortunately, the dynamicity of peopleto-land relationship is sometimes forgotten as it is even the most challenging part in the establishment of the system [22]. In the initial phase, mobilization is done to incite landholders to register their rights; the government, very often supported by donors, avails money and other resources to get the people's rights registered [23]. However, once the records are collected and legal documents issued, there is less pressure to keep the system up to date [5]. Despite the fact that many establishment efforts are an initial success, some attempts fail in the end because no one thought about what comes next after the project donor and expert team have left $[15,22,23]$. No adequate planning for the updating phase is made as the team and the budget were concentrated on the establishment phase. Yet, to update the system requires ongoing resources, energy, and skills [15].

Three perspectives are identified in the literature regarding how to design an updating system. The first one suggests what to not ignore (such as security, affordability, simplicity, 
speed) when establishing a LAS [4-7,24-27], whereas the second perspective focuses on providing frameworks or ways to evaluate or measure how the established system is successful or performing [16,28-30], and the last view explicitly explains what to consider in the updating of land records $[1,5,17,31-34]$. Although these three perspectives are specifically related to the establishment, evaluation, and maintenance of the LAS, it is argued that some of them are cross cutting and very useful in the updating of land records. This is because the initial design of the system has an impact on its future performance and how easy the updating will be. For instance, the registration procedure can be simple, short, and affordable during the initial registration. The same will help when reporting changes in the recorded information, thus helping the system to perform better. Hence, parameters from the above perspectives that are believed to be useful when updating an LIS are summarized in Table 2. Corresponding indicators are added to indicate what is assessed in the case countries.

Table 2. Parameters and indicators to be considered when updating an LIS.

\begin{tabular}{|c|c|c|c|}
\hline \# & Parameters & Assessed Indicators & References \\
\hline 1 & $\begin{array}{l}\text { Simplicity of the system made of simple procedures, } \\
\text { simple language understood by citizens and flexible } \\
\text { ICT which does not require high expertise. }\end{array}$ & $\begin{array}{c}\text { Procedure followed by citizens; } \\
\text { Spoken language used in the database; } \\
\text { Format of the database; } \\
\text { Design and maintain the database; }\end{array}$ & $\begin{array}{c}{[1,4-} \\
7,16,17,26,27,29,31,33]\end{array}$ \\
\hline 2 & $\begin{array}{l}\text { Affordability of the cost to be paid by the applicant } \\
\text { when reporting changes or of the service to be } \\
\text { provided to the applicant. However, the received } \\
\text { fees should allow cost recovery. }\end{array}$ & $\begin{array}{l}\text { Source of funds for the initial registration; } \\
\text { Fee for the initial registration versus fee for } \\
\text { registering a change in land records; }\end{array}$ & {$[4,7,16,17,26,27,29-34]$} \\
\hline 3 & $\begin{array}{l}\text { Speed in processing the application supported by } \\
\text { shorter procedures, completed in less days, and also } \\
\text { faster processing capacity of the infrastructure used. }\end{array}$ & Time required to get new land documents; & {$[4,7,26,27,32,33]$} \\
\hline 4 & $\begin{array}{l}\text { Decentralization of land services to make them closer to } \\
\text { the people in order to reduce the time and the cost. }\end{array}$ & $\begin{array}{l}\text { Administrative location of offices and their } \\
\text { empowerment in the registration process; }\end{array}$ & {$[1,7,16,26,27,29,31]$} \\
\hline 5 & $\begin{array}{l}\text { Accessibility to the database for both the citizens and } \\
\text { local offices. }\end{array}$ & $\begin{array}{l}\text { Possibility of accessing land database by } \\
\text { local offices and citizens }\end{array}$ & {$[5-7,17,26,27,30]$} \\
\hline 6 & $\begin{array}{l}\text { Security of the system and for those who rely on the } \\
\text { database to transact, to issue loan, etc. }\end{array}$ & $\begin{array}{c}\text { Legal value of the issued land document; } \\
\text { Protection of the system from } \\
\text { deliberate abuses; } \\
\text { Back-up the database; }\end{array}$ & {$[4,16,17,29]$} \\
\hline 7 & $\begin{array}{l}\text { Suitability to the circumstance by addressing existing } \\
\text { needs and responding to the societal goals. }\end{array}$ & System addresses societal needs; & {$[4,28,32]$} \\
\hline 8 & $\begin{array}{l}\text { System interconnectivity to facilitate institutions } \\
\text { cooperation and information sharing. }\end{array}$ & Land database is linked to other databases; & {$[5,6,28,31]$} \\
\hline 9 & $\begin{array}{l}\text { Mobilization to raise awareness about the } \\
\text { importance/benefits of registration. }\end{array}$ & $\begin{array}{l}\text { Communicate registration procedure to } \\
\text { the citizens; }\end{array}$ & {$[1,5,7,26,27]$} \\
\hline 10 & $\begin{array}{l}\text { Sustainability of the system characterized by its } \\
\text { upgradability, technological improvement as well } \\
\text { as financially. }\end{array}$ & $\begin{array}{l}\text { Source of funds for updating the system; } \\
\text { Upgrading system structure; }\end{array}$ & {$[1,5,6,16,28-30,32,33]$} \\
\hline 11 & $\begin{array}{l}\text { Compulsory registration so that people have to comply } \\
\text { with the law. }\end{array}$ & $\begin{array}{l}\text { Obligation to register change in } \\
\text { land records }\end{array}$ & {$[1,5]$} \\
\hline 12 & $\begin{array}{l}\text { Incentives to motivate people to register changes } \\
\text { without delays. }\end{array}$ & $\begin{array}{l}\text { Existence of incentives when updating } \\
\text { land records }\end{array}$ & {$[5]$} \\
\hline 13 & $\begin{array}{l}\text { Well organized administration supported by } \\
\text { well-defined goals and tasks of everyone involved }\end{array}$ & $\begin{array}{l}\text { Institutions participating in } \\
\text { land registration }\end{array}$ & {$[28,31]$} \\
\hline 14 & Continuous capacity building of involved staff & $\begin{array}{l}\text { Existence of training offered to } \\
\text { land professionals }\end{array}$ & {$[24,28]$} \\
\hline 15 & $\begin{array}{l}\text { Continuous assessment of the system to know user } \\
\text { needs, societal needs and for customer satisfaction }\end{array}$ & $\begin{array}{l}\text { Availability of tools to assess the } \\
\text { effectiveness of the land registration }\end{array}$ & {$[24,28,32]$} \\
\hline 16 & Political support as decision makers & $\begin{array}{c}\text { Type of support offered by the government } \\
\text { in land registration (initial and } \\
\text { updating phase) }\end{array}$ & [24] \\
\hline
\end{tabular}




\section{Land Registration Programs in the Selected Countries}

Land registration aims at specifying who holds what type of right on which piece of land. At the end of the exercise, collected land records include, among others, the person holding right, the form of the right, and the asset on which the right is held [18]. Developing and updating land records is a public need, which will prevent potential challenges that could lead to unsecure tenure thus hinder land investment [3]. Unfortunately, with $70-75 \%$ of land rights mostly reported as undocumented in the developing world [19,33], recording land updates is hardly done in the majority of LISs making them outdated and unreliable [35].

The land registration programs considered in this research (see Table 3) mainly aimed to ensure tenure security to rightful landholders with a particularity to vulnerable groups, boost land market and investment in land, issue legal land documents, improve the effectiveness of LAS and of the land registration specifically, prevent and reduce land disputes, and produce land records. The land records were systematically collected either for some areas (Cambodia, Ethiopia, Kyrgyzstan, Nepal, and Thailand) or for a specific category of land (Kenya, Mexico, Namibia) or for the entire territory (Rwanda). Whilst there are few particularities, these programs adopted an unconventional approach: Local people participated in the registration process, neighbors were present during boundary demarcation, images were used to collect cadastral data, and provisional land records were displayed for public inspection before the issuance of legal land documents.

In Mexico, the ejido (communal lands) members had to agree through a vote that the registration program can start in their area and also to approve the sketch map delimitating the community's outer boundary [36-38]. Though the land records were collected by land professionals in Kyrgyzstan, community representatives together with government officials formed a specialized land commission that received objections during public display [39]. Under the ongoing second-level rural land registration, Ethiopia is upgrading its systems by including cadastral data that were not collected during the first phase of the registration $[9,40]$. Kenya and Namibia are also still doing land registration, though, in the former country, the term 'native reserves' is no longer used, as the naming was intended to differentiate land held by Kenyans with the ones occupied by British settlers (Interview done on 16 January 2021).

An overview of the characteristics per country program is given in Table 3. 
Table 3. Case study countries with their respective land registration programs.

\begin{tabular}{|c|c|c|c|}
\hline Country & Program & Purpose & Approach for Collecting Land Data \\
\hline \multirow[t]{2}{*}{ Ethiopia } & $\begin{array}{l}\text { 1st level rural land registration } \\
\text { (1998 up to the 2nd level } \\
\text { registration) }[9,40-43]\end{array}$ & $\begin{array}{l}\text { Provide tenure security to rural farmers, } \\
\text { reduce land disputes and address land } \\
\text { issues had by vulnerable groups }\end{array}$ & $\begin{array}{l}\text { Land records collected by the kebele land administration committee (elected from local people) } \\
\text { supported by land professionals at woreda level. Landholders had to apply for registration and } \\
\text { the provided information were verified in the field (in the presence of neighbors). The } \\
\text { registered parcels were spatially located referring to neighbors in the north, south, east and } \\
\text { west. No cadastral map was produced. }\end{array}$ \\
\hline & $\begin{array}{l}\text { 2nd level rural land registration } \\
\text { (2013 up to now) [44] }\end{array}$ & $\begin{array}{l}\text { Upgrade the 1st level land records with } \\
\text { cadastral records }\end{array}$ & $\begin{array}{l}\text { The kebele land administration committee, para-surveyors and the field data recorder, all } \\
\text { selected from the local community, formed a registration team. The parcel boundaries are } \\
\text { drawn on aerial images in the presence of the registration team, landholders and neighbors. }\end{array}$ \\
\hline Kenya & $\begin{array}{l}\text { Registration of Native Reserves } \\
\text { (1965-1966 up to now) [45-47] }\end{array}$ & $\begin{array}{l}\text { Ensure tenure security of these communal } \\
\text { land, promote intensive agriculture and put } \\
\text { together land records }\end{array}$ & $\begin{array}{l}\text { The adjudication team (appointed by the minister) and the adjudication committee (local } \\
\text { people familiar with customary holdings) collected land records using printed aerial images. } \\
\text { The images were taken after hedges were planted by landholders over their parcel boundaries. } \\
\text { Within the area under registration, land claims were received before proceeding with } \\
\text { parcel demarcation. }\end{array}$ \\
\hline Rwanda & $\begin{array}{l}\text { Land Tenure Regularization } \\
\quad \text { (2009 to 2013) [12,48-51] }\end{array}$ & $\begin{array}{l}\text { Register and issue legal land documents; } \\
\text { minimize and prevent land disputes; } \\
\text { promote land investment and ensure tenure } \\
\text { security to vulnerable groups. }\end{array}$ & $\begin{array}{l}\text { The land committee and para-surveyors (both selected from the local people) collected land } \\
\text { records by using printed aerial images on which were drawn parcel boundaries in the presence } \\
\text { of landholders and their neighbors. The parcels were systematically registered without } \\
\text { exception and claims were posted for public inspection before issuing the final land certificate. }\end{array}$ \\
\hline Kyrgyzstan & $\begin{array}{l}\text { Registration of Land and Real } \\
\text { Estates (2000 to 2007) [39,54,55] }\end{array}$ & $\begin{array}{l}\text { Put in place a consistent land registration, } \\
\text { ease the existing procedures used in land } \\
\text { and real estate transactions. }\end{array}$ & $\begin{array}{l}\text { The registration team (legal and mapping specialist) was going house to house demarcating } \\
\text { boundaries and collecting proof of ownership. In the absence of proof, the registration team } \\
\text { tried to find the real owner in the archive. If nothing was found, a provisional registration was } \\
\text { done until the landholder was able to prove their right. The provisional lists and maps were } \\
\text { displayed for thirty days where land commission received objections. }\end{array}$ \\
\hline Namibia & $\begin{array}{l}\text { Communal Land Registration } \\
\text { (2003 up to now) [56-60] }\end{array}$ & $\begin{array}{l}\text { Register and verify customary land rights, } \\
\text { introduce long term leases over communal } \\
\text { land, encourage land investment and } \\
\text { provide infrastructure support }\end{array}$ & $\begin{array}{l}\text { The landholder has to apply and their claims are assessed by traditional authority (TA) and } \\
\text { approved by the communal land board (CLB). Together with the ministry regional staff, the TA } \\
\text { and CLB verify if the parcel is unassigned and conduct a systematic parcel mapping using GPS } \\
\text { and aerial images. The claims are posted for seven days before the registration certificate can } \\
\text { be issued to the claimant. }\end{array}$ \\
\hline
\end{tabular}


Table 3. Cont.

\begin{tabular}{|c|c|c|c|}
\hline Country & Program & Purpose & Approach for Collecting Land Data \\
\hline Nepal & $\begin{array}{l}\text { Systematic Cadastral } \\
\text { Registration (1965 to 1995) } \\
{[61,62]}\end{array}$ & $\begin{array}{l}\text { Record landowners and tenants, and what } \\
\text { they respectively held so as to limit the } \\
\text { ownership to land holding ceiling and } \\
\text { protect the right of tenant farmers }\end{array}$ & $\begin{array}{l}\text { The cabinet is the one to decide what area/district to be registered. After officially notifying } \\
\text { the concerned area, land records were collected and handed to the office in charge for any } \\
\text { claim. After settling disputes and claims, ownership certificates were issued. }\end{array}$ \\
\hline Mexico & $\begin{array}{l}\text { Certification of Ejido (communal } \\
\text { land) (1992-2007) [36-38] }\end{array}$ & $\begin{array}{l}\text { Provide tenure security to land holders in } \\
\text { order to increase investment }\end{array}$ & $\begin{array}{l}\text { Prior to the registration, a general assembly made of ejido members had to approve it through } \\
\text { voting. Once approved, an ejidal commission drafted a map showing the inner and outer } \\
\text { boundaries of the ejidos and the map was again approved by the general assembly through a } \\
\text { vote. The INEGI (Instituto Nacional de Estadistica y Geográfica-National Institute of Statistics } \\
\text { and Geography) and the ejido members conducted a detailed registration by using a GPS. } \\
\text { Produced maps were displayed for two weeks for objections and approved by the ejido } \\
\text { assembly through voting. The RAN (Registro Agrario Nacional-National Agrarian Registry) } \\
\text { would use the map as basis to issue certificates to individuals whose holdings were approved. }\end{array}$ \\
\hline Cambodia & $\begin{array}{l}\text { Land Management and } \\
\text { Administration Project (2002 to } \\
\text { 2013) }[63,64]\end{array}$ & $\begin{array}{l}\text { Improve land tenure security and promote } \\
\text { the development of efficient land markets }\end{array}$ & $\begin{array}{l}\text { Cadastral staff, supported by the local authorities, filled the registration form with ownership } \\
\text { information and demarcated parcel boundaries using ortho-photo. The lists of owners and } \\
\text { village maps were displayed for thirty days for public inspection. Cadastral staff and local } \\
\text { authorities tried to resolve disputing claims. The updated ownership list and maps are printed } \\
\text { and approved by provincial governor and land titles issued based on the approved documents. }\end{array}$ \\
\hline
\end{tabular}




\section{Good Practices in Updating Land Records from the Case Study Countries}

Though ground experiences and most literature reveal that the updating of the land records seems to be a forgotten activity $[15,22,23]$, first and foremost, resources supporting updating phase (procedures, legal, and institutional frameworks) have to be part of the land registration project plan and ready to be used [5]. This argument backs our discussion and specifically the identification of good practices in updating land records from the case-study countries. Good practices are those suggestions from land experts (see Table 2) that were made workable. Parameters considered when updating the land records are used to analyze updating procedures from countries for which land registration programs were studied (see Table 3).

Though obstacles hindering updating systems in the case study countries exist, the good news is that resources supporting the updating of land records are in place and this shows that updating is considered as important and needed. The available resources include the formal updating procedures and ways to communicate them to citizens; institutions handling land registration; government involvements in registration activities; digital database of land records; legal framework supporting registration activities; capacity building of staff involved in land registration; and means to assess the effectiveness of the registration of land. These are the first good practices to highlight. Further good practice analyses from the case study countries from the perspective of the sixteen assessment criteria identified in Table 2 are discussed here.

\subsection{Simplicity of the System}

To encourage the use of the updating system, procedures should be made simple and easier, developed in a language understood by citizens $[4,16,29,31]$, and the technology used in the system design should be adapted to the local knowledge $[5,6]$ as people tend to fear what they do not understand [4]. Once worked on, they are among the strongest sides to realize the simplicity of the updating system.

Based on the interviews, all the case-study countries possess formal procedures to be followed by citizens when updating land records. However, most of these procedures are not that simple as citizens need support to go through them. Fortunately, the support can be found at lower level where the services are sought. For Kenya, Nepal, and Mexico, procedures are somewhat complex as citizens have to consult land professionals (e.g., lawyers, skilled ejidatario, licensed people) to help them to go through the process. Rwanda is the only country possessing an online application system, which could make the process easier for those who are familiar with technology but somehow complex for unskilled citizens.

The findings show that for all countries considered here, both the design and the maintenance of the databases is done by local and foreign experts except in Nepal and Thailand where only local technicians do the whole work. This is positive as involving local people can help to create a sustainable system that can operate even if there is no external support or in cases of delay. According to the results, apart from Kenya where it is mainly a paper-based dataset, the designed land record databases are digital. With regard to the languages used, the findings are that most of the systems are designed considering the native language widely spoken in the country. This again facilitates the accessibility of the system by many citizens.

With the existence of updating procedures, the inclusion of native language to design the land records dataset, and the involvement of local experts in the design and the maintenance of the system, all of these combined could enable the updating of the system to be simplified. This is a strong point towards encouraging the reporting of change in land records.

\subsection{Affordability of the Cost}

The cost of land registration determines its future acceptance [4]. They can be kept low, but not too low to be a burden to the government $[1,7,26,27]$, as landholders have to bear a part or all the cost for registering subsequent changes to support the self-financing 
of the system [1]. The difference between the updating fees and the initial registration fees should not be too big, at least in the beginning, in order to increase public awareness on the advantages of registration [1].

The results show that for the initial land registration, no payment was required for registering land in Ethiopia, Kenya, Nepal, and Mexico, while it was equal or less than US\$6 in Thailand, Namibia, and Rwanda. In Cambodia, the fees were charged based on the size, being US\$2.50 for one hectare of rural agriculture land, whereas in Kyrgyzstan, it is US\$ 65 (unfortunately, no additional information was obtained that would explain the criteria for this payment). The cost is reasonable for citizens as confirmed by the respondents, though it turns out to be a burden to the government, which funded the initial registration activities and is often supported by donors in the majority of countries.

Though they can vary depending on the type of transaction, the findings are that the fees for registering change in land records are less than US\$10 in Ethiopia, Mexico, Namibia, Kyrgyzstan, and Thailand but beyond US\$30 in Kenya and Rwanda. They depend on land value in Nepal, whereas in Cambodia, they are calculated based on location and use of land (e.g., in rural area, they are almost US $\$ 25$ for agriculture land and US\$50 for residential).

Here one can see that the majority of country considered in this study managed to keep the fees low (below US\$10). As says one interviewee from Cambodia, "There [are] usually informal fees which dissuade people from engaging in this process". These informal fees may include transport, per diem (in case witnesses are needed in the process), or fees to speed up the process-the calculating of which may not be easy as some are a secret between the giver and the receiver.

\subsection{Speed}

Speed refers to the time it takes to get a new land document when applying for registering a change in the land records [32]. The updating process should be completed in less days $[7,26,27,34]$ to motivate the applicant to come again, otherwise they may opt for shortcuts leading to informality [3].

In most case-study countries, the results show that the updating period is equal or above one month. In Namibia, it takes three months minimum as that is when the communal land board meets to assess the applications. In Nepal, the process requires a maximum of five days, while in Kyrgyzstan, one day is enough to get a new land document. The good thing is that when all the documents are complete in Ethiopia and Kenya or during the land registration campaign in Rwanda (known as 'land week'), the process is completed in a single day.

The possibility of processing the application in one day (when all the requirements are in order) proves that the process can be shortened if there is proper and regular communication about requirements, available resources (human and technical) supporting updating, and continuous training for the staff. Fortunately, means to sensitize citizens about updating procedures and the attached benefits as well as trainings of involved staff are done in all the case countries. With more effort in availing resources, where the speed is not currently achieved, it may be achieved as well.

\subsection{Decentralization}

In order to improve the correctness of the records $[7,26,27]$ and allow equitable access to all $[17,29]$, land registration services have to be closer to the people: The distance and the time taken to register change in land records are reduced [1] and motivation to register changes in land records is increased.

Based on the results, the land registration services are available at a local level in all the case countries except in Mexico where the RAN (Registro Agrario Nacional-National Agrarian Register) that administer the ejido (communal land) operates only at the state (province) level. For these countries, there is a closer communication of local administration with the upper levels during the registration process either when processing the application (as everyone has a role to play depending on their position) or when seeking information 
to process it. For instance, in Ethiopia, the court decision is needed prior to processing inheritance, whereas in Kenya, Namibia, and Rwanda, the application is received at lower level and continues to be processed at upper levels by different actors.

Although the move from one desk to another and sometimes from one building to another may delay the registration process, the availability of information and services at a lower level is a positive asset that may encourage the updating of land records.

\subsection{Accessibility to the Database}

A database open to its users is one of the things facilitating the updating as anyone has the possibility to check if the information registered in their names are correct or not $[5,6,17]$.

It is very positive that all countries under consideration in this study thought about opening the database to other people apart from those managing it. In all these countries, the findings are that the database is accessed by citizens, with the exception of Cambodia, and by local officers in all countries excluding Mexico (no local offices). Citizens from these countries can access the data in different ways: By physically going to the office in charge (all the case countries excluding Cambodia); through a specific website (Kyrgyzstan, Mexico, Rwanda, and Thailand); or using the mobile phone (Rwanda and Thailand). Based on the results, the fees charged vary from free to US $\$ 2$. The same as citizens, providers of land services at the local level access the land database via website or phone or by going or sending an email to the institution in charge.

\subsection{Security of the System}

Anyone participating in land transactions needs to be sure that they are dealing with the right person and that the law will protect their rights when needed $[4,17]$. The legal value of the certificate/title issued after registering land rights and the existence of a backup of records used to produce a land document is key [16].

In all of the case countries, the findings are that the land document issued to landholders has a legal value, i.e., it can be used as ownership evidence in case of disputing claims. Except for Kenya where the database is paper based, backup that will help to restore the records in case of problems exists in all the other countries. As specified by the respondents from Ethiopia, Nepal, Rwanda, and Thailand, there are different access levels to the digital database for local officers, and what they can do on the database depends on their role in the process and the assigned area. The issuance of legal land documents after registration and the existence of backup for the stored land records are among good practices leading to a secured system.

\subsection{Suitability to the Circumstance}

To be accepted and used, the registration programs will have to respond to societal needs [28,32]. In case there is no link between the designed system and what people need, updating changes in land records may be difficult as no one is seeing the relevance of the system.

As discussed under Section 4, ensuring tenure security, boosting land market and land investment, issuing land certificate/title, improving the effectiveness of land registration, handling land disputes, and producing land records are the main purposes for which the explored land registration programs were conducted. Normally, the degree to which these purposes were achieved or how the developed system is addressing the current societal needs is assessed through specific research. As some of the land experts interviewed undertook or participated in such assessments, their thoughts are relevant. The good thing is that most respondents think that these goals were achieved in the registration programs and also that the established system is responding to the current societal needs. It is not surprising that there are also some who said that the purposes were partially achieved and that the system is not really addressing the actual societal needs. Designing an LAS and assessing its achievement are continuous activities because the system has 
to be adapted to the dynamicity of people-to-land relations. As such, hitting the target precisely and accurately seems to be hard as this target is continuously moving based on the societal needs.

\subsection{System Interconnectivity}

When there is connection between databases hosted by different institutions (and not as individual silos), some processes are shortened or removed, and the service provision is sped up, which facilitates the system updating [31]. Besides, this connectivity is crucial to create a data sharing platform (Spatial Data Infrastructure-SDI) leading to faster communication among actors about decisions affecting land registration [1].

It is unfortunate to find that, with these benefits, only Kyrgyzstan and Rwanda have the land records database linked with other databases (no information for Thailand). As an example, in Rwanda, the database of land records is connected to tax collection, building permits, population registers, court, mortgage registrations (used by banks), and subsidized agriculture inputs.

Before data sharing, the priority may be to have a well-functioning land registration and secured database and to have these may take time. Thus, system interconnection can be considered as one step further when developing an LAS. This could explain why the majority of the studied case countries do not have this interconnection, although willingness to do so is another parameter that should not be ignored.

\subsection{Mobilization}

Information is power. Thus, informing citizens about what to do and where to go when seeking land registration services is essential to encourage the updating of the database but also raise awareness about its benefits $[5,7,26,27]$.

In addition to having formal procedures for updating land records, it is worthy to mention that, in all the explored countries, there are mechanisms in place to communicate these procedures to citizens. The results show that the communication is done through different means: Media (TV or radio), public meeting, written materials (e.g., brochures, manuals), physically going to the institution in charge of registration activities or their website, social media, or informing local leaders (village headman, traditional leader) who will dispatch the information where they live. This mobilization may be an indication that the willingness to have updated databases exists.

\subsection{Sustainability of the System}

Financial and technical sustainability is critical for land information system [28,30]. Sustainability should be ensured through mechanisms ensuring a continuous maintenance $[17,29]$. If the system is not self-financed, the government should at least be able to allocate budget for its operation.

Respondents from the case-study countries indicated that the government (supported by donors for many of them) allocates budget for updating land records. In Rwanda, the collected land revenues go in the national treasury and come back as allocated budget, whereas Cambodia and Kyrgyzstan affirmed having already self-financed land registration. Ethiopia and Rwanda have a plan to introduce a self-financed system.

The technical sustainability depends on the available budget to cover the cost of upgrading the system so as to adapt it to new technologies and societal needs $[5,6]$. The results show that, except in Kyrgyzstan and Cambodia, other countries upgraded, in one way or the other, the technical structure of the land database designed during the considered initial land registration programs (no information for Namibia). Ethiopia and Rwanda changed the version of their LIS (currently at version 5.1.3 and version 4 respectively); Kenya adapted laws related to technological advancement and did minimal computerization; Mexico updated the software used to store the data; Nepal moved from LAN (Local Area Network) to WAN (Wide Area Network) and is digitizing the database; and Thailand changed their mapping technology. 
Financial and technical sustainability of the updating system seems to be uncertain as the main funds are from donors, and considering that, a few countries have a self-financed system or are planning to introduce it.

\subsection{Compulsory Registration}

Generally, there is a legal framework backing land registration activities that specify whether it is compulsory or not to register land rights (including those rights obtained through transfers) [5]. As the registered information is the foundation to make decisions on the legally accepted landholder, registration has to be compulsory [1]. Even though the law is not enough to increase the number of applications for change registration, it is believed that more people would register change when the registration is compulsory than when it is not. There is a kind of motivation and/or pressure as there is a legal protection for those whose rights are registered and whose information are up to date.

Fortunately the findings show that, except in Cambodia, Kenya, and Mexico, in all other countries, it is compulsory to register land transfers or other changes in land records. This is a strong stimulus in the updating of land records.

\subsection{Incentives}

In business, there are promotional periods to attract buyers or to empty stores. If this technique works well in business, why not in land services? Incentives can be given to those who register certain changes (e.g., succession) to motivate people to register them and on time [5].

It is worthy to report that, in the countries under study (no information for Cambodia), half of them offer incentives for some registration activities while others do not offer anything. It is free to register co-ownership between spouses or parcel merging in Ethiopia and boundary or area correction in Rwanda. Additionally, in Rwanda, during land registration campaigns (or land week), there is a mobile team of land professionals going from place to place, offering land services and issuing land certificates on the same day for those transferring land. In Thailand, they lower taxes or fees during promotional periods, while in Mexico, an interviewee explained that "they are regular actualization campaigns organized by the Procuraduria Agraria (Agrarian Procuracy) aiming at motivating and facilitating the registration of successor lists (testament) by ejidatarios, without any cost and in their village". Though there are no additional data collected from other countries under study, experience from Rwanda is that the received applications to update land records increase during land week campaigns (personal experience of the first author). This is a recommendable good practice.

\subsection{Well Organized Administration}

Institutions involved in land registration should each have clearly defined tasks in the process, and cooperate and communicate well with each other [28]. Overlapping responsibilities hinder service provision to the public and it may negatively affect the number of received applications [1]. Besides, there can be shortage of competent staff when there are too many offices [31]. The registration process can be long due to duplication or contradiction in the activities performed during application processing; citizens may be confused about what service to find where; conflicts between institutions may make citizens victims, and so forth.

Unfortunately, the results show that the majority of countries under study (Kenya, Mexico, Namibia, Nepal, and Rwanda) have more than one institutions on the same level (ministerial, regional or district) dealing with land registration. Only few countries have one institution handling land matters represented from national to local levels. Cambodia has the Ministry of Land Management, Urban Planning, and Construction at the national level and the Cadaster \& Land Department at the province and district level. In Thailand, the Department of Land under the Ministry of Interior has branches at province and at district levels in Bangkok metropolitan, while in Kyrgyzstan, the State Agency on Land 
Resources has branches at a regional level; and in Ethiopia, the land registration services are offered at woreda level.

Though it was not possible to determine all the respective responsibilities of institutions carrying out land registration in the countries considered, it is believed that the higher the number of involved institutions, the higher the difficulty in specifying the role of each of them. There is a high probability of having overlaps when there are many institutions. In addition, as said one interviewee from Namibia: "It could actually be a smooth process, but due to fact that there are so many stakeholders involved ..., it lengthens the process". The number of involved institutions in the registration may also affect the registration speed.

\subsection{Continuous Capacity Building}

Updating land records is a daily exercise requiring adequate level of trained professionals [15]. The provider of land services at all levels needs to be updated about new technologies in their field as well as be informed about how the system is coping with the changing environment [28]. This can be done through workshops or short/long term trainings.

It is amazing to find that, in all the countries explored, trainings are offered to staff working in land registration. The subjects addressed include land administration and management, land valuation, land laws, cadastral surveying, IT-based courses, customer care, geo-information sciences, land use planning, and so on. This is a strength to keep. Referring to Mexico, which mentioned that the trainings have currently been stopped due to lack of resources, it is argued that due to the importance of having capacitated staff involved in the land registration, continuous capacity building has to be budgeted for when allocating funds to registration activities.

\subsection{Continuous Assessment of the System}

One way to know if the system is operating effectively is to get information from its users. User satisfaction should be aimed for in service provision including land registration services, otherwise they may be discouraged to report the changes in land records [32]. Regular review of the registration process should take place to assess the system efficiency and effectiveness [28].

Fortunately, the results show that methods to assess the effectiveness of the land registration exist in all the case countries except in Ethiopia (no information for Namibia). They include suggestion boxes, monitoring and evaluation, change management systems, audits, customer satisfaction surveys, conferences, seminars, research, governance score cards, business reports, claims received on social media or in land registration campaigns, field visits by senior management, and so forth. It is believed that these tools are very useful and should be used properly in order to know what to improve in the registration activities.

\subsection{Political Support}

It is hard, even impossible, to undertake a program if there is no buy-in from policy makers. Political support is among the requirements to implement the land registration programs [24].

Based on the fact that these programs were implemented, there is no doubt that the government gave its consent. This was ascertained by respondents from all of the programs studied who said that the government supported the initial land registration, and the updating of the system is fully under its responsibility. The government offered and looked for financial and technical support; availed infrastructures; obtained human resources and trained them; elaborated laws and regulation to support the programs; and so on. This is a strong incentive in the updating of land records.

\section{Conclusions}

Keeping up-to-date land records used to be challenging, and the existing literature focuses mainly on weaknesses in the updating process. This paper proves that there 
are good, recommendable practices in the nine countries considered. They include the existence of infrastructure supporting updating available in all of the case countries; for the majority, the systems are simplified and registration fees are reasonable; services are decentralized; the digital database is secured and accessible by citizens and local officers; mobilization is done to raise awareness about registration; the legal framework is there to emphasize the importance of registration; incentives are offered for some transactions to motivate people to report them on time; staff are trained; the system effectiveness is assessed; and the political support is offered.

Efforts are still needed in order to shorten updating procedures, introduce datasharing platforms, ensure financial and technical sustainability, and reduce the number of institutions involved in the registration process. Though it is worthy to adapt the registration program to the societal needs, it was found to be difficult to assess whether the target was hit as the needs are continuously changing.

Whilst several countries' situations in terms of updating land records are depicted in this paper based on the literature and informants' information, further research may be conducted based on field observations per case country.

Author Contributions: The manuscript is part of an ongoing research done by M.B. under the guidance of her supervisors J.Z. and B.K.A. Conceptualization; methodology, formal analysis; writing—original draft preparation, M.B.; writing—review and editing, J.Z. and B.K.A. All authors have read and agreed to the published version of the manuscript.

Funding: Funding of the publication costs for this article has kindly been provided by the School of Land Administration Studies, University of Twente, in combination with Kadaster International, the Netherlands. The ongoing PhD research is funded by DAAD (Deutscher Akademischer AustauschdienstGerman Academic Exchange Service) under its In-Country/In-Region Scholarship Program SLGA (Strengthening Capacities for Land Governance in Africa), 2017 (57377251).

Institutional Review Board Statement: Not applicable.

Informed Consent Statement: Not applicable.

Data Availability Statement: The data presented in this study are available on request from the corresponding author. The data are not publicly available in order to respect the privacy of the respondents.

Acknowledgments: The authors thank the anonymous respondents from the case study countries who provided information that lead to the production of this manuscript.

Conflicts of Interest: The authors declare no conflict of interest.

Appendix A List of Countries That Used Systematic Land Registration Program

\begin{tabular}{cccc}
\hline Africa & America & Asia & Europe \\
\hline Benin & & Brunei & \\
Burkina Faso & & India & \\
Côte d'Ivoire & Israel & \\
Ethiopia & & Malaysia & Belgium \\
Ghana & & Nepal & Poland \\
Kenya & & Pakistan & Spain \\
Lesotho & Argentina & Philippines & Switzerland \\
Madagascar & Mexico & Sri Lanka & Armenia \\
Mozambique & & Turkey & \\
Namibia & & Kyrgyzstan & \\
Rwanda & & Thailand & \\
Tanzania & & Vietnam & \\
Uganda & & Cambodia & 5 \\
\hline 13 & 2 & 13 & \\
\hline
\end{tabular}




\section{References}

1. Larsson, G. Land Registration and Cadastral Systems: Tools for Land Information and Management; Longman Scientific \& Technical: New York, NY, USA, 1991.

2. Dale, P.F.; McLaughlin, J.D. Land Administration; Oxford University Press: Oxford, UK, 1999.

3. Williamson, I.; Enemark, S.; Wallace, J.; Rajabifard, A. Land Administration for Sustainable Development; ESRI Press Academic: Redlands, CA, USA, 2010.

4. Simpson, S.R. Land Law and Registration; Cambridge University Press: New York, NY, USA, 1976.

5. Enemark, S.; McLaren, R.; Lemmen, C. Fit.For-Purpose Land Administration Guiding Principles for Country Implementation Securing Land; United Nations Human Settlements Programme (UN-Habitat): Nairobi, Kenya, 2016; p. 132.

6. Enemark, S.; Bell, C.K.; McLaren, R. Fit-For-Purpose Land Administration; Joined Publication FIG \& World Bank: Copenhagen, Denmark, 2014.

7. Zevenbergen, J.; Augustinus, C.; Antonio, D.R.; Bennett, R.M. Pro-Poor Land Administration: Principles for Recording the Land Rights of the Underrepresented. Land Use Policy 2013, 31, 595-604. [CrossRef]

8. Williamson, I.P. Cadastral Survey Techniques in Developing Countries—with Particular Reference to Thailand. Aust. Surv. 1983, 31, 496-512. [CrossRef]

9. Deininger, K.; Ali, D.A.; Holden, S.; Zevenbergen, J. Rural Land Certification in Ethiopia: Process, Initial Impact, and Implications for Other African Countries. World Dev. 2008, 36, 1786-1812. [CrossRef]

10. Deininger, K.; Augustinus, C.; Enemark, S.; Munro-Faure, P. Innovations in Land Rights Recognition, Administration, and Governance; The World Bank: Washington, DC, USA, 2010; p. 251.

11. Byamugisha, F.F.K. Securing Africa's Land for Shared Prosperity: A Program to Scale Up Reforms and Investments; Africa Development Forum; Agence Française de Développement and the World Bank: Washington, DC, USA, 2013.

12. Ngoga, T.H. Rwanda's Land Tenure Reform: Non-Existent to Best Practice; CABI Publishing: Boston, MA, USA, 2018.

13. Wohlin, C. Guidelines for Snowballing in Systematic Literature Studies and a Replication in Software Engineering. In Proceedings of the 18th International Conference on Evaluation and Assessment in Software Engineering, London, UK, 13-14 May 2014. [CrossRef]

14. Danglot, B.; Vera-Perez, O.; Yu, Z.; Zaidman, A.; Monperrus, M.; Baudry, B. A Snowballing Literature Study on Test Amplification. J. Syst. Softw. 2019, 157, 110398. [CrossRef]

15. Jing, Y.; Bennett, R.; Zevenbergen, J. Up-to-Date' in Land Administration: Setting the Record Straight. In Innovative Cadastre and Land Rights Management; FIG: Abuja, Nigeria, 2013.

16. FIG. FIG Statement on the Cadastre. Available online: https://www.fig.net/resources/publications/figpub/pub11/figpub11.asp (accessed on 26 June 2018).

17. FAO. Voluntary Guidelines on the Governance of Tenure: At a Glance; FAO: Rome, Italy, 2012.

18. Henssen, J. Land Registration and Cadastre Systems: Principles and Related Issues; Technische Universität München: Munich, Germany, 2010.

19. Unger, E.-M.; Bennett, R.M. Fit-For-Purpose Land Administration for All: A Guide for Surveyors on Adoption and Adaptation of Fit-For-Purpose Land Administration; Netherlands' Ministry of Foreign Affairs and Kadaster: The Hague, The Netherlands, 2019.

20. Ali, D.A.; Deininger, K.; Mahofa, G.; Nyakulama, R. Sustaining Land Registration Benefits by Addressing the Challenges of Reversion to Informality in Rwanda. Land Use Policy 2019, 104317. [CrossRef]

21. Simbizi, M.C.D.; Bennett, R.M.; Zevenbergen, J. Land Tenure Security: Revisiting and Refining the Concept for Sub-Saharan Africa's Rural Poor. Land Use Policy 2014, 36, 231-238. [CrossRef]

22. Van der Molen, P. The Dynamic Aspect of Land Administration: An Often-Forgotten Component in System Design. Comput. Environ. Urban Syst. 2002, 26, 361-381. [CrossRef]

23. Magis, M.; Zevenbergen, J. Towards Sustainable Land Administration Systems: Designing for Long-Term Value Creation. In Engaging the Challenges-Enhancing the Relevance; FIG: Kuala Lumpur, Malasia, 2014.

24. Dale, P.F.; McLaughlin, J.D. Land Information Management: An Introduction with Special Reference to Cadastral Problems in Third World Countries; Oxford University Press: New York, NY, USA, 1988.

25. Williamson, I.P. Land Administration "Best Practice" Providing the Infrastructure for Land Policy Implementation. Land Use Policy 2001, 18, 297-307. [CrossRef]

26. Zevenbergen, J.; Augustinus, C.; Antonio, D. Designing a Land Records System for the Poor; United Nations Human Settlements Programme (UN-Habitat): Nairobi, Kenya, 2012.

27. Hendriks, B.; Zevenbergen, J.; Bennett, R.; Antonio, D. Pro-Poor Land Administration: Towards Practical, Coordinated, and Scalable Recording Systems for All. Land Use Policy 2019, 81, 21-38. [CrossRef]

28. Steudler, D. A Framework for the Evaluation of Land Administration Systems. Ph.D. Thesis, The University of Melbourne, Melbourne, Australia, 2004.

29. Burns, T. Land Administration Reform: Indicators of Success and Future Challenges. Agric. Rural Dev. 2007, $37,244$.

30. Deininger, K.; Selod, H.; Burns, A. The Land Governance Assessment Framework: Identifying and Monitoring Good Practice in the Land Sector; The World Bank: Washington, DC, USA, 2012. [CrossRef]

31. Hanstad, T. Designing Land Registration Systems for Developing Countries. Am. Univ. Int. Law Rev. 1998, 13, 647-703. 
32. Chimhamhiwa, D.; van der Molen, P.; Mutanga, O.; Rugege, D. Towards a Framework for Measuring End to End Performance of Land Administration Business Processes-A Case Study. Comput. Environ. Urban Syst. 2009, 33, 293-301. [CrossRef]

33. Enemark, S. Fit for Purpose: Building Spatial Frameworks for Sustainable and Transparent Land Governance; The World Bank: Washington, DC, USA, 2013; p. 18.

34. World Bank. Methodology for Registering Property. Available online: https://www.doingbusiness.org/en/methodology/ registering-property (accessed on 26 June 2019).

35. Moreri, K.; Fairbairn, D.; James, P. Issues in Developing a Fit for Purpose System for Incorporating VGI in Land Administration in Botswana. Land Use Policy 2018, 77, 402-411. [CrossRef]

36. Dower, P.C.; Pfutze, T. Land Titles and Violent Conflict in Rural Mexico. J. Dev. Econ. 2020, 144, 102431. [CrossRef]

37. Kutzman, D. Land Certification and Deforestation: In The Impact of Procede on Land Use in Mexico; The World Bank: Washington, DC USA, 2012; p. 30.

38. Barnes, G.; DiGiano, M.; Augustinus, C. Ejido Land Tenure and Registration System: Mexico Case Study-Synthesis Report; Synthesis Report Report; United Nations Human Settlements Programme (UN-HABITAT): Nairobi, Kenya, 2015; p. 30.

39. Gainer, M. Cementing the Right of Ownership: Land Registration in Kyrgyzstan, 1999-2009. Innovations for Successful Societies; Princeton University: Princeton, NJ, USA, 2017.

40. Bezu, S.; Holden, S. Demand for Second-Stage Land Certification in Ethiopia: Evidence from Household Panel Data. Land Use Policy 2014, 41, 193-205. [CrossRef]

41. Deininger, K.; Zevenbergen, J.; Ali, D.A. Assessing the Certification Process of Ethiopia's Rural Lands. In Colloque International "Les Frontières de la Question Foncière-At the Frontier of Land Issues"; Montpellier, France, 2006; p. 14. Available online: https:/ /land.igad.int/index.php/documents-1/countries/ethiopia/rural-development-1/282-assessing-the-certificationprocess-of-ethiopia-s-rural-lands / file (accessed on 6 December 2018).

42. Bureau of Environment Protection, Land Administration and Use (BoEPLAU). Land Registration and Certification: Experiences from the Amhara National Regional State in Ethiopia. Bureau of Environment Protection, Land Administration and Use; BoEPLAU: Amhara, Ethiopia, 2010.

43. Bezabih, M.; Kohlin, G.; Mannberg, A. Trust, Tenure Insecurity, and Land Certification in Rural Ethiopia. J. Socio Econ. 2011, 40, 833-843. [CrossRef]

44. Land Investment For Transformation (LIFT). Second-Level Land Certification Manual; Version 3.1; DAI Europe: London, UK, 2018.

45. Caukwell, R.A. Cadastral Survey in Kenya and Its Role in the Development of the Country. Master of Sciences; University of Nairobi: Nairobi, Kenya, 1977.

46. Wayumba, R.N. Impacts of Different Land Registration Systems on Communal Tenure in Kenya. Ph.D. Thesis, University of Otago, Dunedin, New Zealand, 2014.

47. Wayumba, G. A Historical Review of Land Tenure Reforms in Kenya. IJSRES 2015, 2, 45-51.

48. Sagashya, D.; English, C. Designing and Establishing a Land Administration System for Rwanda: Technical and Economic Analysis. In Innovations in Land Rights Recognition, Administration, and Governance; Joint Organizational Discussion Paper; The World Bank: Washington, DC, USA, 2010; pp. 43-59.

49. Republic of Rwanda. National Land Policy. Ministry of Lands, Environment, Forests, Water and Mines. 2004. Available online: https:/ / rema.gov.rw / rema_doc/Policies/National_land_policy_english_version_.pdf (accessed on 24 August 2018).

50. Simbizi, M.C.D.; Bennett, R.M.; Zevenbergen, J. Pro-Poor Land Administration. In Advances in Responsible Land Administration; Taylor \& Francis: Boca Raton, FL, USA, 2015; pp. 17-36.

51. Biraro, M.; Bennett, R.M.; Lemmen, C. Accelerated Land Administration Updates. In Advances in Responsible Land Administration; Taylor \& Francis: Boca Raton, FL, USA, 2015; pp. 145-161.

52. Williamson, I.P. Cadastral and Land Information Systems in Developing Countries. Aust. Surv. 1986, 33, 27-43. [CrossRef]

53. Rattanabirabongse, V.; Eddington, R.A.; Burns, A.F.; Nettle, K.G. The Thailand Land Titling Project-Thirteen Years of Experience. Land Use Policy 1998, 15, 3-23. [CrossRef]

54. The World Bank. Kyrgyz Republic-Land and Real Estate Registration Project (English): Project Appraisal; The World Bank: Washington, DC, USA, 2000.

55. The World Bank. Kyrgyz Republic-Land and Real Estate Registration Project (English): Project Performance Assessment Report; The World Bank: Washington, DC, USA, 2010.

56. Werner, W. Tenure Reform in Namibia's Communal Areas. J. Namib. Stud. Hist. Politics Cult. 2015, 18, 67-87.

57. Werner, W. Land, Livelihoods and Housing Programme 2015-2018 Working Paper. Work. Pap. 2015, 1, 17.

58. Meijs, M.; Kapitango, D. Namibia Land Management Series Number 2: Communal Land Registration; Namibia Institute for Democracy, Ministry of Lands and Resettlement: Windhoek, Namibia, 2009.

59. Kapitango, D.; Meijs, M. Land Registration Using Aerial Photography in Namibia: Costs and Lessons. In Innovations in Land Rights Recognition, Administration, and Governance; Joint Organizational Discussion Paper; The World Bank: Washington, DC, USA, 2010; pp. 60-72.

60. Matthaei, E. What Does Registration of Communal Land Mean to Namibians? Available online: http:/ / www.focusonland.com/ countries / case-study-what-does-registration-of-communal-land-mean-to-nambians- / (accessed on 26 November 2020). 
61. Acharya, B.R. Spatial information management in Nepal. In Spatial Information Management for Sustainable Real Estate Market-Best Practice Guidelines on Nation-Wide Land Administration; UN/ECE-Working Party on Land Administration: Athens, Greece, 2003; Available online: https://www.oicrf.org/-/spatial-information-management-in-nepal (accessed on 18 December 2018).

62. Acharya, B.R.; Bhattarai, M.P. Cadastre in Nepal: Towards the Beginning of a Land Information System. FIG Newsl. 1996, 14, 8-10. Available online: https://www.oicrf.org/-/cadastre-in-nepal-towards-the-beginning-of-a-land-information-system (accessed on 18 December 2020).

63. Biddulph, R. Cambodia's Land Management and Administration Project. UNU WIDER 2015, 1-14. [CrossRef]

64. Boramy, S. Systematic Land Titling in Cambodia Is the Component 3 of the Land Management and Adminsitration Project (LMAP). In FIG Commission 7 Annual Meeting 2008 and Open Symposium on Environment and Land Administration "Big Works for the Defence of the Territory"; OICRF: Gelderland, The Netherlands, 2008; Available online: https:/ /www.oicrf.org/-/systematic-land-titling-incambodia-is-the-component-3-of-the-land-management-and-adminsitration-project-lmap (accessed on 20 January 2021). 